\title{
Neonatal Near Miss Cases of Different Health Facilities
}

\author{
Manandhar $\mathrm{SR}^{1}$, Manandhar $\mathrm{DS}^{2}$, Adhikari $\mathrm{D}^{3}$, Shrestha $\mathrm{J}^{4}$, Rai $\mathrm{C}^{5}$, Rana $\mathrm{H}^{6}$, Paudel $\mathrm{M}^{7}$
}

\begin{abstract}
Introduction: The near miss concept and the criterion-based clinical audit are proposed as useful approaches for obtaining such information in newborn health care. There is currently no Standard definition and criteria for neonatal near miss especially for the community level intervention. Thus, lifesaving interventions could be an entry point to initiate the development of the neonatal near-miss definition. Mother and Infants Research Activities and Health Right International (HRI) developed a new tool for assessing neonatal near miss cases based on the Community based newborn care package programme. This is a part of operational research programme on strengthening the health facilities of Electoral constituency No; 2 of Arghakhanchi district of Nepal. The objective of this study was to identify and analyze neonatal near miss cases at different health facilities of Electoral constituency No; 2 of Arghakhanchi district, Nepal. Materials and Methods: One day of training on identifying neonatal near miss cases was given by an expert at Arghakhanchi district hospital to the health facilities staff in two groups. Health facility staffs were trained on identifying neonatal near miss cases and completing the modified neonatal near miss case forms. Neonatal near miss cases were documented for nine months period. Results: There were a total of 28 cases of neonatal near miss reported from different health facilities. Among them, $90 \%$ babies were delivered at health facility and $72 \%$ babies were of normal birth weight. Low birth weight incidence is $21 \%$ among near miss cases. Neonatal near miss contributed possible severe bacterial infection/ severe infection $47 \%$, birth asphyxia in $43 \%$ cases and very low birth weight 7\%. Conclusions: Birth asphyxia and PSBI were the two most common causes of neonatal near miss in the health facilities of Arghakhanchi district. There is a need to improve the quality of neonatal care in health facilities to properly manage these neonatal near miss cases which were referred to higher centre.
\end{abstract}

Key words: Birth asphyxia, neonatal near miss, possible severe bacterial infection (PSBI)

\section{Introduction}

$T^{\prime}$

he near miss concept and the criterion-based clinical audit are proposed as useful approaches for obtaining such information
'Dr. Sunil Raja Manandhar, MBBS, MD, Assistant Professor, Department of Paediatrics, Kathmandu Medical College Teaching Hospital (KMCTH), ${ }^{2}$ Prof. Dr. Dharma S Manandhar, MBBS, DCH, MRCP (UK), FRCP Lon \& Edin, FNAMS, FIAP, Head, Department of Paediatrics, KMCTH \& President and Executive Director, MIRA, ${ }^{3}$ Mr. Dhruba Adhikari, Research Officer, Mother and Infant Research Activities (MIRA), ${ }^{4}$ Mr Jyoti Raj Shrestha, Research Coordinator, Mother and Infant Research Activities (MIRA), ${ }^{5} \mathrm{Ms}$ Chandra Rai, Project Director and Country Representative, Health Right International, ${ }^{6} \mathrm{Mr}$. Hari Rana, Training and Operation Coordinator, Health Right International. ${ }^{7}$ Mr. Mohan Paudel, Monitoring and Evaluation Coordinator, Health Right International.

\section{Address for correspondence:}

Dr. Sunil Raja Manandhar, Assistant Professor, Department of Paediatrics

Kathmandu Medical College Teaching Hospital, Sinamangal, Kathmandu, Nepal E-mail: drsunilraja@gmail.com Mobile: 9803812218

\section{How to cite}

Manandhar S, Manandhar DSM, Adhikari D, Shrestha J, Rai C, Rana H, Paudel M. Neonatal Near Miss Cases of Different Health Facilities. J Nepal Paediatr Soc 2014;34(2):115-118.

doi: http://dx.doi.org/10.3126/jnps.v34i2.9880

This work is licensed under a Creative Commons Attribution 3.0 License.

\section{(c) (i)}

in newborn health care. Neonates with severe complications at birth or during the neonatal period who nearly died but survived constitute neonatal near miss 
cases. There is however, no standard WHO definition or internationally agreed identification criteria for neonatal near miss cases. Development of such criteria would facilitate the use of neonatal near miss as a measure of quality of newborn care tool ${ }^{1}$. There is currently no standard definition and criteria for neonatal near miss especially for the community level intervention.

Pileggi $\mathrm{C}$ et $\mathrm{al}^{2}$ described neonatal near miss cases as severe life threatening condition at birth, e.g. gestational age of $<30$ weeks, birth weight $<1.5 \mathrm{~kg}$ and Apgar score at 5 minutes $<7$. Souza JP et al $^{3}$ described neonatal near miss as consisting of clinical organ dysfunction criteria, e.g. tachypnea, bradycardia, etc. and laboratory marker of organ dysfunction, e.g. $\mathrm{SPO}_{2}$ less than $80 \%$, serum $\mathrm{pH}<7.1$, etc. Similarly, Knijf $A D$ et al described neonatal near miss cases as the babies with signs of respiratory failure/dysfunction, cardiac failure/dysfunction, CNS failure/dysfunction, etc ${ }^{4}$.

But in developing countries like Nepal, the above mentioned criteria may not be followed properly in the community setting as most of the health facilities in the community are providing level I and partly level II newborn care. Thus, life-saving interventions could be an entry point to initiate the development of the neonatal near-miss definition; together with other indicators of increased risk of death, e.g. infants who survived extreme preterm birth, very low birth weight, severe birth asphyxia, severe birth trauma, and neonatal sepsis could be considered as neonatal near miss cases. MIRA and HealthRight developed a new tool for assessing neonatal near miss cases based on the CB-NCP programme. This is a part of operational research (OR) programme by Mother and Infant Research Activities (MIRA) and HealthRight International (HRI) on strengthening the health facilities of electoral constituency No; 2 (EC 2) of Arghakhanchi district in Nepal. One part of operational research is to train health facility staff on newborn care and setting up neonatal corners at health facilities and conducting neonatal near miss analysis in the health facilities to improve neonatal quality care. The operational research study was started on $1^{\text {st }}$ October 2010 till $14^{\text {th }}$ April 2013 (Chaitra 2069).

The objective of this study were to identify and analyze neonatal near miss cases at different health facilities of EC 2 of Arghakhanchi district, Nepal.

\section{Material and Methods}

As a part of operational research for strengthening the health facilities of EC 2, one day training on identifying neonatal near miss cases was given at Arghakhanchi district hospital to the staff of health facilities EC no.2 of Arghakhanchi district for two days, for two groups. 37 health staff including doctor, staff nurse, Health Assistant (HA), and Auxiliary nurse midwives (ANM) of different health facilities were trained on completing the modified neonatal near miss case forms. Neonatal near miss cases were documented for nine months duration.

\section{Criteria determined for neonatal near miss cases:}

Any one of the following conditions was taken as a neonatal near miss case in this study:

1. Any neonate who received bag and mask ventilation from a Female Community Health Volunteer (FCHV), Village Health Worker (VHW), Maternal and Child Health Worker (MCHW), or any health worker during neonatal resuscitation.

2. Any neonate who was managed for Very Low Birth Weight (birth weight $<1.5 \mathrm{~kg}$ ) by a FCHV, VHW, MCHW or any health worker

3. Any neonate treated \&/or referred for any one of the following ten conditions of Possible Severe Bacterial Infection (PSBI) ${ }^{5}$.

1. Unable to breastfeed

2. Lethargic or unconscious

3. Fast breathing

4. Severe chest indrawing

5. Grunting

6. Fever

7. Hypothermia

8. Umbilical discharge with redness extending up to surrounding skin

9. Ten or more than ten pustules over skin of baby or one big abscess

10. Weak or absent cry

Data were entered in SPSS 16 and frequency and tabulation were obtained. Causes of neonatal near miss cases were analyzed.

\section{Results}

There were a total of 28 cases of neonatal near miss reported from different health facilities of EC No.2 constituency of Arghakhanchi district. Among them, 18 cases were reported from Arghakhanchi district hospital, five cases from Thada PHC, two cases each from Subarnakhal HP and Pokharathok HP. 
While analyzing 28 babies with neonatal near miss condition, $90 \%$ (25) babies were delivered at health facility whereas three babies (10\%) were delivered at home depicted in Fig. 1. According to birth weight category, most of the babies $72 \%$ (20) were of normal weight, $21 \%$ (6) babies were low birth weight and $7 \%$ (2) babies were very low birth weight, which were depicted in Fig 2.

While analyzing resuscitative procedures applied in 28 near miss cases, 60\% (17) were provided initial steps including suction and tactile stimulation and $40 \%$ (11) did not required any form of resuscitation. Among those 17 asphyxiated babies, 65\% (11) received bag and mask ventilation by health workers which were depicted in Fig. 3. While analyzing the outcome of neonatal near miss babies $57 \%$ (16) were discharged from health facilities after treatment by health personnel whereas $43 \%$ (12) were referred to higher tertiary centre depicted in Fig. 4. Among 12 referred cases, three cases each were of septicemia, birth asphyxia and high fever. Two babies were of very lowbirth weight and one baby had pneumonia.

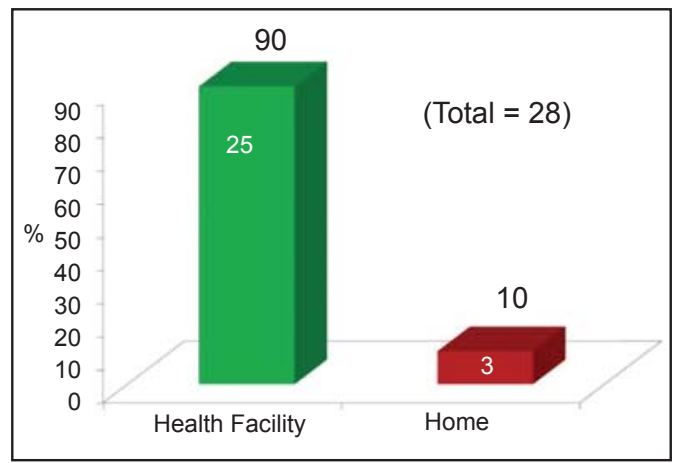

Fig. 1: Delivery place of neonatal near miss cases

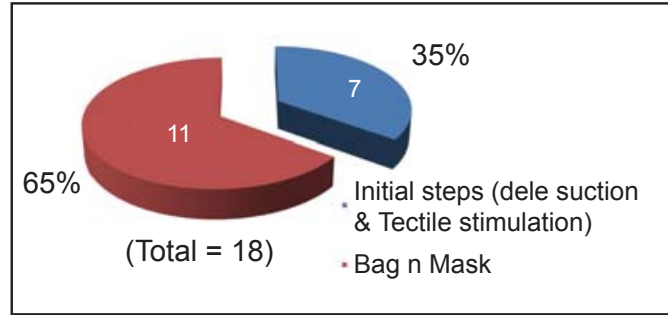

Fig. 3: Resuscitation procedure done in neonatal near miss cases
Analysis of near miss cases showed Possible severe bacterial infection (PSBI)/severe infection 47\% (13), Birth asphyxia in 43\% (12), very lowbirth weight $7 \%$ (2) and meconium aspiration 3\% (1) which are depicted in Fig. 5 and Table 1. Among six PSBI cases, three cases with high fever, two cases are hypothermia and one case is of umbilical sepsis.

Table 1: Causes of neonatal near miss cases

\begin{tabular}{|c|l|c|c|}
\hline SN & Suspected Diagnosis & Frequency & $\%$ \\
\hline 1 & $\begin{array}{l}\text { Possible severe bacterial } \\
\text { infection (PSBI)/severe } \\
\text { infection }\end{array}$ & 13 & 47 \\
\hline 1.1 & $\begin{array}{l}\text { Possible severe bacterial } \\
\text { infection (PSBI) }\end{array}$ & 6 & \\
\hline 1.2 & Septicemia & 5 & \\
\hline 1.3 & Pneumonia & 2 & \\
\hline 2 & Birth asphyxia & 12 & 43 \\
\hline 3 & Very Low birth weight & 2 & 7 \\
\hline 4 & Meconium aspiration & 1 & 3 \\
\hline & Total & $\mathbf{2 8}$ & $\mathbf{1 0 0}$ \\
\hline
\end{tabular}

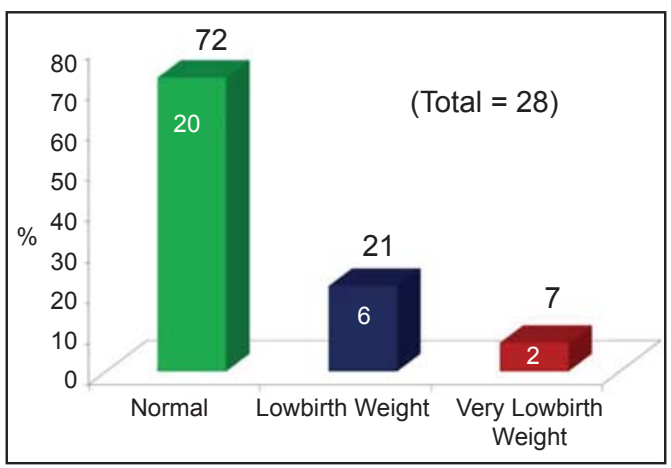

Fig. 2: Weight category of neonatal near miss case

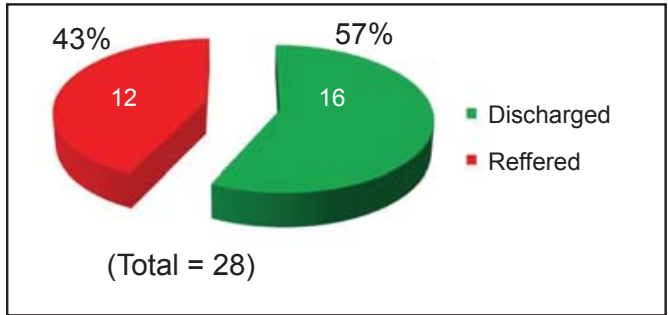

Fig. 4: Outcomes of neonatal near miss cases

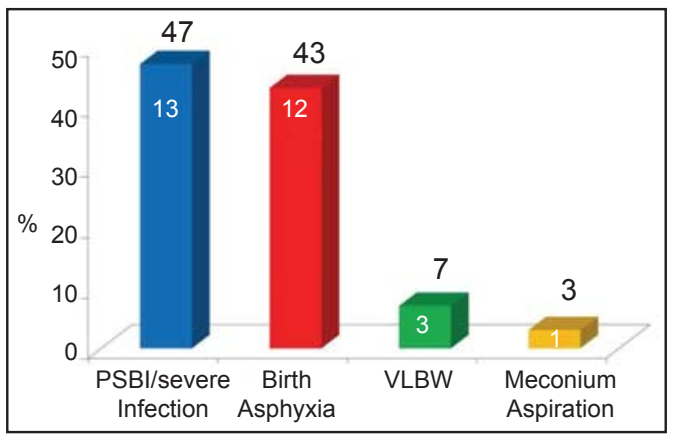

Fig. 5: Neonatal near miss category 


\section{Discussion}

Possible severe bacterial infection (PSBI)/ severe infection were the commonest cause (47\%) of neonatal near miss followed by birth asphyxia (43\%). Among $60 \%$ (17) of the asphyxiated babies, some form of neonatal resuscitation procedures were provided. Avenant $\mathrm{T}^{6}$ also postulated intrapartum asphyxia as a commonest cause (12.9\%) of neonatal near miss which is also resembled in this study.

A social practice of wrapping babies with dirty clothes in the community and improper hand washing before touching babies could be important contributing factors for neonatal sepsis as severe infection was the commonest cause $(47 \%)$ of neonatal near miss. Similarly, it was seen that $57 \%$ (16) near miss cases were treated successfully by health personnel. This could be due to impact of proper neonatal near miss identification and treatment after neonatal near miss training.

In a study done by Pileggi Castro $\mathrm{C}$ et $\mathrm{al}^{7}$ defined one of the neonatal near miss criteria as birth weight $<1.5 \mathrm{~kg}$ with a sensitivity of $72.6 \%$ (70.6-74.5) and specificity of $97.4 \%$ (97.4-97.5), which is included in this study also as one of the criteria for neonatal near miss. So, such studies will help to postulate definite criteria for diagnosing neonatal near miss perticulalrly in community setting.

\section{Conclusions}

Severe infection/ PSBI and birth asphyxia were the two most common causes of neonatal near miss in the health facilities of Arghakhanchi district.

\section{Recommendations}

There is a need to improve the quality of antenatal care and intrapartum management to reduce asphyxia in the health facilities. There is still need to improve the quality of neonatal care at the health facilities to properly manage these neonatal near miss cases which were referred to higher centre. There is a need of regular training to health staff and regular supply of essential equipments like warm cot, Resuscitaire, Ambu bag at least in district hospital for improving the quality of neonatal care in health facilities in order to manage these neonatal near miss cases which were referred to higher centres. The training on neonatal near miss could have a good impact on managing high risk babies. For development of proper guideline for neonatal near miss tool, such more studies on neonatal near miss are required.

Acknowledgement: Our sincere thanks go to Dr. Yam Bahadur Basnet, DHO Arghakhanchi district, Mr. Lila Ram Gautam, DPHO and the Arghakhanchi district public health office team for their kind support and cooperation during this operational research process. We are acknowledging to the health staff including medical officers, nurses and paramedical staff of the Arghakhanchi District Hospital, Thada PHC, Narpani HP, Pokharathok HP, Subarnakhal HP and Siddhara HP. At last but not the least, thanks are due to the mothers and relatives who agreed to be interviewed and other. Funding: Health Right International with support from USAID

Conflict of Interest: This study was done with technical support from Mother and Infant Research Activities (MIRA).

Permission from IRB: Yes

\section{References}

1. Say L. Neonatal near miss: a potentially useful approach to assess quality of newborn care. J Pediatr (Rio J) 2010;86(1):1-2.

2. Pileggi C, Souza JP, Cecatti JG, Faúndes A. Neonatal near miss approach in the 2005 WHO Global Survey Brazil. J Pediatr (Rio J) 2010; 86(1):21-26.

3. Souza JP, Gülmezoglu AM, Carroli G, Lumbiganon P et al. The world health organization multicountry survey on maternal and newborn health: study protocol. BMC Health Services Res 2011;11:286.

4. De Knijf A, Pattinson RC. Confidential enquiries into quality of care of women in labour using Hypoxic Ischemic Encephalopathy as a marker. Facts Views Vis Obgyn 2010;2(4):219-25.

5. Ministry of Health and Population, Government of Nepal. FCHV classification card [pamphlet]. Morang: Department of Public Health Office: 2006.

6. Avenant T. Neonatal near miss: a measure of the quality of obstetric care. Best Pract Res Clin Obstet Gynaecol 2009;23(3):369-74. doi: 10.1016/j. bpobgyn.2008.12.005. Epub 2009 Feb 6.

7. Pileggi Castro C, Camelo JS, Perdon GC, MussiPinhata MM, Cecatti JG, Mori R et al. Development of criteria for identifying neonatal near-miss cases: analysis of two WHO multi country cross-sectional studies. BJOG 2014; 121(Suppl. 1):110-18. 